\title{
DEVELOPMENT OF AN ELECTRICAL HAND-HELD OLIVE HARVESTER
}

\section{M. IBRAHIM * \\ ABSTRACT}

The objective of this study was developed a hand held olive harvester suitable for small farms. The portable machine was designed, fabricated and evaluated for its performance and techno-economic feasibility. Some physical and mechanical properties (dimensions, mass, fruit detachment force / mass ratio) of olive fruits that are related to the mechanical harvesting were measured and considered in the machine design. The developed machine was evaluated at three levels of head speed (700, 1100 and $1500 \mathrm{rpm})$ and two types of head length $\left(H_{1}\right.$ has stick length of $6 \mathrm{~cm}$ and $\mathrm{H}_{2}$ has stick length of $17 \mathrm{~cm}$ ). The evaluation criteria were: productivity $(\mathrm{Pm})$, fruit removal percentage $(F R)$ and fruit damage percentage (FD), consumed energy (CE) and harvesting cost (HC). From the obtained results, it is deduced an equation and contour chart for the harvesting machine to predict the suitability of the machine to removal the fruit with different olive variety. The most suitable working parameters of the machine at $1100 \mathrm{rpm}$ and $1500 \mathrm{rpm}$ with $\left(\mathrm{H}_{2}\right)$ where the maximum value of evaluation parameter were Pm of $91.5 \mathrm{~kg} \mathrm{~h}^{-1}, \mathrm{FR}$ of $97.7 \%$, FD of $6.23 \%$, CE of $1.31 \mathrm{~W} \mathrm{~h} \mathrm{~kg}^{-1}$ and HC of $0.26 \mathrm{L.E} \mathrm{kg}$.

Keywords: olive; hand-held; harvesting; fruit detachment; fruit damage.

\section{INTRODUCTION}

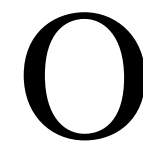
live tree (Olea europaea $\mathbf{L}$.) is one of the most important crops in all the Mediterranean countries. In Egypt, olive is a key part of the agriculture sector, where a cultivated area of about 67293 of hectares, and an average year production of 694.3 thousand tons (FAOSTAT, 2018). Olive production faces many problems, some of them related to the low product price and high production costs. So, it is important to reduce costs and improve fruit quality. The harvesting operations of olive are the most costly and they contain olive fruit detachment from the tree and collection of the detached olives.

\footnotetext{
${ }^{*}$ Assoc. Prof., Ag. Eng. Dept., Fac. of Agric., Cairo University.
} 
The olive harvesting mechanization systems allow reducing costs where it needs less manpower and increasing quality (better productivity rates) (Amirante and Tamborino, 2012). The olive harvesting cost is the most expensive operation, it represents between 25 and $60 \%$ of total cropping cost (IOOC, 2015). In Egypt, the most olives farms are harvested by the manually methods. Vieri and Sarri (2010) mentioned that the hand harvesting has low productivity which reaches $50 \%-70 \%$ of the cultivation revenue. Özarslan et al., (2001) reported that hand harvesting represents about $50 \%$ of the total production costs and $50-60 \%$ of the total labor requirement for harvesting operations. The best harvesting operation is definite as the ability to harvest more than $90 \%$ of the olive fruits, in the shortest time, lowest number of labor, minimum damage to the olive fruits and minimum risk for labor (Mansour et al., 2018). Hegazy (2009) reported that harvesting methods can be classified to: manual, simple hand-held equipment, fully mechanized. Famiani et al. (2010) stated that the common operating harvesting machine of olive can be divided to two types: oscillating or vibrating or turning combs, and shaking hooks. Deboli et al. (2014a) stated that hand held olive harvesters are: beaters, combs and hooks. Beaters are machines with an oscillating head equipped with thin sticks in carbon fibre; harvesting is obtained by direct impact of sticks on olives or by vibration transmitted to the willowy branches. Deboli et al. (2014b) stated that the hand harvest of olives is one of the most expensive operations in the table olives production, and the electric hand machines can be replaced the hand harvesting. Paschino et al. (2010) carried out a preliminary study on the use of electric hand held harvesters, equipped with titanium undulating teeth coated with silicone. Olive harvesting by hand-held harvester is used with a low capital investment and when full mechanization is not possible. It represents a minimum level of mechanization because the machine is carried by the operator (Famiani et al., 2010). Famiani et al. (2008) and O'brien et al., (1986) mentioned that the factors affecting the mechanical harvesting of tree fruit were frequency, amplitude, direction of shaking, fruit size and detachment force to fruit weight ratio. Factors affecting mechanical olive harvesting are tree shape, canopy density, 
orchard density, pruning and the cultivar (Tombesi et al, 2002 and Ferguson et al, 2010).

Farinelli et al., (2012) reported that the factors that affected the fruit detachment were variety, maturity, fruit weight, detachment force, geometry of the fruit, tree pruning and specifications of the harvester.Another important parameter is the limb length, it is length from the attachment point with fruit bearing branch to the attachment point with each fruit from the bearing branch (Castillo-Llanque and Rapoport, 2009) Visco et al., (2004) demonstrated that the major problem of mechanical olive harvesting; is generating sufficient fruit removal force transmitted to the olive abscission zone, to detach the olive fruit without damage. Fruit detachment is mainly caused by three oscillation modes; the pendulum, the tilting, and the rotational (or twisting) (Zhou et al., 2016). The objective of this study was to design and evaluate a hand-held machine for harvesting olive in small farms.

\section{MATERIALS AND METHODS}

The developed hand- held harvesting machine had been designed, manufactured and evaluated at the Faculty of Agriculture, Omar ElMukhtar University, El-Beida - Libya. The main criteria for designing the prototype of machine for harvesting fruits were: easy design, simple to use, low weight, high productivity, less fruit damage, and low operating costs.

\subsection{Tree and fruit parameters related to harvesting olives fruit}

\subsubsection{Dimensions of the olive tree}

An important factor for designing the machine is to know the characteristics of the olive tree. The measurements were carried out on 15 trees of manzanillo cultivar. The trees had the same dimensional and morphological characteristics and were planted on a $12 \times 12 \mathrm{~m}$ spacing. The dimensional characteristics of olive trees are reported in table (1).

Table (1): Main dimensional characteristics of the olive trees

\begin{tabular}{lllll}
\hline $\begin{array}{l}\text { Trunk } \\
\text { circumference } \\
(\mathbf{c m})\end{array}$ & $\begin{array}{l}\text { Trunk } \\
\text { Height } \\
(\mathbf{m})\end{array}$ & $\begin{array}{l}\text { Canopy } \\
\text { diameter } \\
(\mathbf{m})\end{array}$ & $\begin{array}{l}\text { Tree } \\
\text { Height } \\
(\mathbf{m})\end{array}$ & $\begin{array}{l}\text { Limb } \\
\text { length } \\
(\mathbf{c m})\end{array}$ \\
\hline $340 \pm 45$ & $1.6 \pm 0.3$ & $11.3 \pm 1.6$ & $5.0 \pm 0.4$ & 15 \\
\hline
\end{tabular}




\subsubsection{Physical and mechanical properties of olive fruit}

A sample of 100 mature olive fruits was collected randomly to measure some physical and mechanical properties of fruit which related to the designing of harvesting machine.

The ratio of fruit detachment force to fruit mass $\left(\mathrm{R}_{\mathrm{Fm}}\right)$ is used to decide the suitability of olive fruit for mechanical harvesting. The fruit detachment force was measured by using the hand dynamometer with 50 $\mathrm{N}$ capacity. The hand dynamometer was attached to the selected fruit and a pulling force was gradually increased until the fruit was separated. The maximum force was recorded as the static detachment force. Each detached fruit was then weighed. The ratio of the $\left(\mathrm{R}_{\mathrm{Fm}}\right)$ was calculated using following equation:

$$
R_{F m}=\frac{F}{m}
$$

Where

$\mathrm{R}_{\mathrm{Fm}} \quad$ : The ratio of the fruit detachment force to mass, $\mathrm{N} \mathrm{g}^{-1}$.

F : Fruit detachment force, N.

$\mathrm{m} \quad$ : Fruit mass, g.

\subsection{Force analysis of olive fruit detachment}

It was proposed to the mass of tree limb is ignored in the analysis; and hence, Fruit motion trajectory is namely pendulum motion.

The detachment of the olive fruit is entirely governed by tensile forces acting on the fruit, and detachment occurs when the internal forces due to the motion of the fruit become greater than the fruit detachment force (Tsatsarelis, 1984). An oscillated olive fruit has two forces acting on it. One is downward force of gravity. The second is tension in the limb which changes in both size and direction as the fruit swings. When fruit swings through the bottom of its motion path, the fruit has maximum speed and requires the maximum force to hold it in its circular path.

The centripetal force is a combination of the tension force from the limb and the fruit weight of the fruit. The magnitude of the centripetal force on the pendulum changes as the fruit swings back-and-forth, because the component of fruit weight that is along the radius changes (Fig. 1). 
At any fruit position, when the limb makes angle $\theta$ with the vertical, the fruit is moving slower than at equilibrium and the centripetal force is thus lower than at equilibrium. The centripetal force is given by the following equation:

$$
F_{\text {centripetal }}=\underset{\theta}{\text { at } \theta} T_{\theta}-m g \cos \theta
$$

Where

$\mathrm{T}$ : Tension force exerted on limb olive, $\mathrm{N}$.

$\mathrm{m}$ : Mass of olive fruit, $\mathrm{kg}$.

g : Acceleration gravity, $\mathrm{m} \mathrm{sec}^{-1}$.

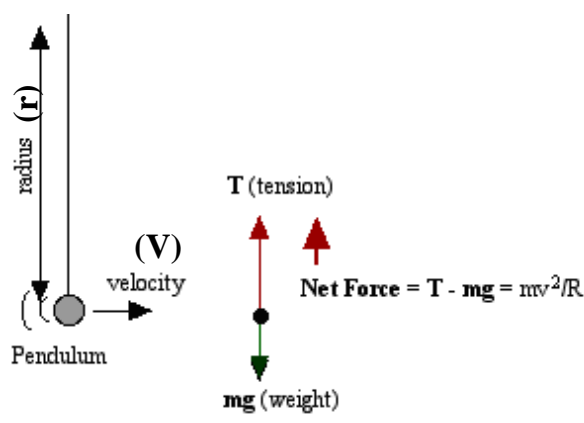

Free body diagram at maximum

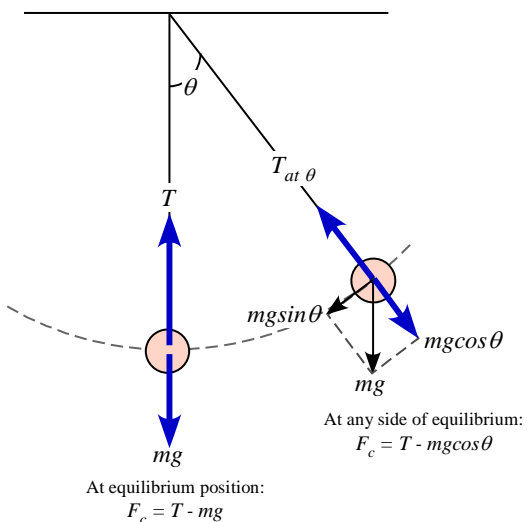

Fig. (1): Fruit motion under oscillation motion.

The maximum centripetal force at the bottom of its swing, because at the equilibrium position is the fruit is moving the fastest, and $F_{\text {centripetal }}$ is greater because speed is greater than the maximum centripetal force, it is given by following equation:

$$
\underset{\substack{\text { centripetal } \\ \text { at equilibrium }}}{F_{\text {a }}}=T-m g
$$

The net centripetal force is directed toward the center of the circular motion and its magnitude can be calculated by the following equation:

$$
F_{\text {centripetal }}=m r \omega^{2}=\frac{m v^{2}}{r}
$$

Where

$\mathrm{V} \quad$ : The linear velocity of olive fruit, $\mathrm{m} \mathrm{sec}^{-1}=\frac{2 \pi r \mathrm{~N}}{60}$. 
$\mathrm{N}:$ Velocity of the head, rpm.

$\omega \quad$ : Angular velocity of olive fruit, $\mathrm{rad} \mathrm{sec}^{-1}$.

$\mathrm{r} \quad$ : Length of peduncle, $\mathrm{m}$.

According to Newton's Third Law of Motion, action and reaction are equal and opposite. Therefore, the olive fruit must exert a force radially outwards and equal magnitude of centripetal force. This force is known as centrifugal force $(\mathrm{Fc})$ and it equals to the centripetal force.

If olive fruit makes the pendulum motion, the fruit would be detached if the centrifugal force becomes greater than the static tensile force (The fruit detachment force). Equation (4) can be rewritten as the following equation:

$$
v^{2}=\left(\frac{F}{m}\right) \cdot r
$$

By applying the pervious equation in the harvesting olive fruit, the fruit will be detached when the square linear velocity of the olive fruit is higher or equal the value of (F/m.r), it can be written as the following equation:

$$
\frac{v^{2}}{10} \geq\left(\frac{F}{m}\right) \cdot r
$$

Where

$\mathrm{V} \quad$ : The linear velocity of the head harvester, $\mathrm{m} \mathrm{sec}^{-1}=\frac{2 \pi r \mathrm{~N}}{60}$.

$\mathrm{N}$ : Velocity of the head, rpm.

$\mathrm{F} / \mathrm{m}$ : Detachment force to mass ratio of olive fruit, $\mathrm{N} \mathrm{g}^{-1}$.

$\mathrm{r} \quad$ : Length of limb, cm.

By applying the previous equation in the head of the machine, the square linear speed of the head $\left(\mathrm{V}^{2} / 10\right)$ should be higher or equal to the value $\left(\frac{F}{m} \cdot r\right)$ of olive fruit variety to get fruit detachment.

\subsection{Developed harvesting machine}

The manufactured machine for harvesting the olive fruits consists of the following main parts: a) Harvesting mechanism, b) Extension rod, and c) Power unit. Figure (3) shows the developed machine and its specifications. 

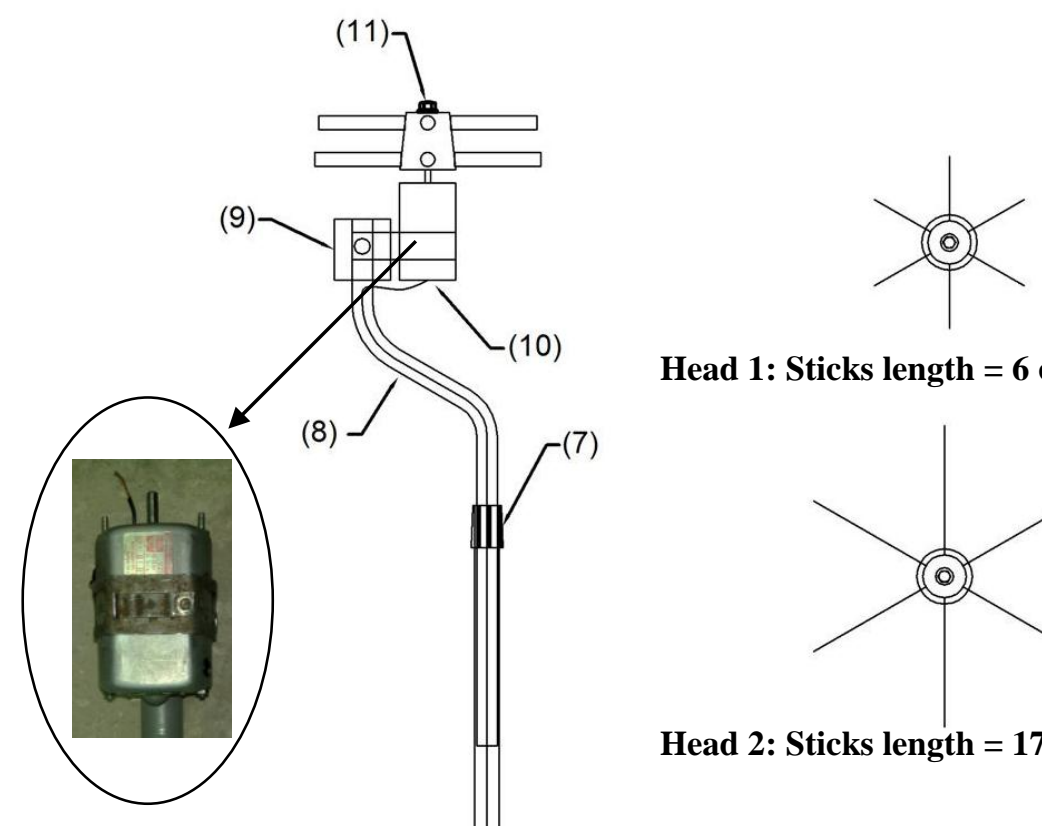

Head 1: Sticks length $=6 \mathrm{~cm}$
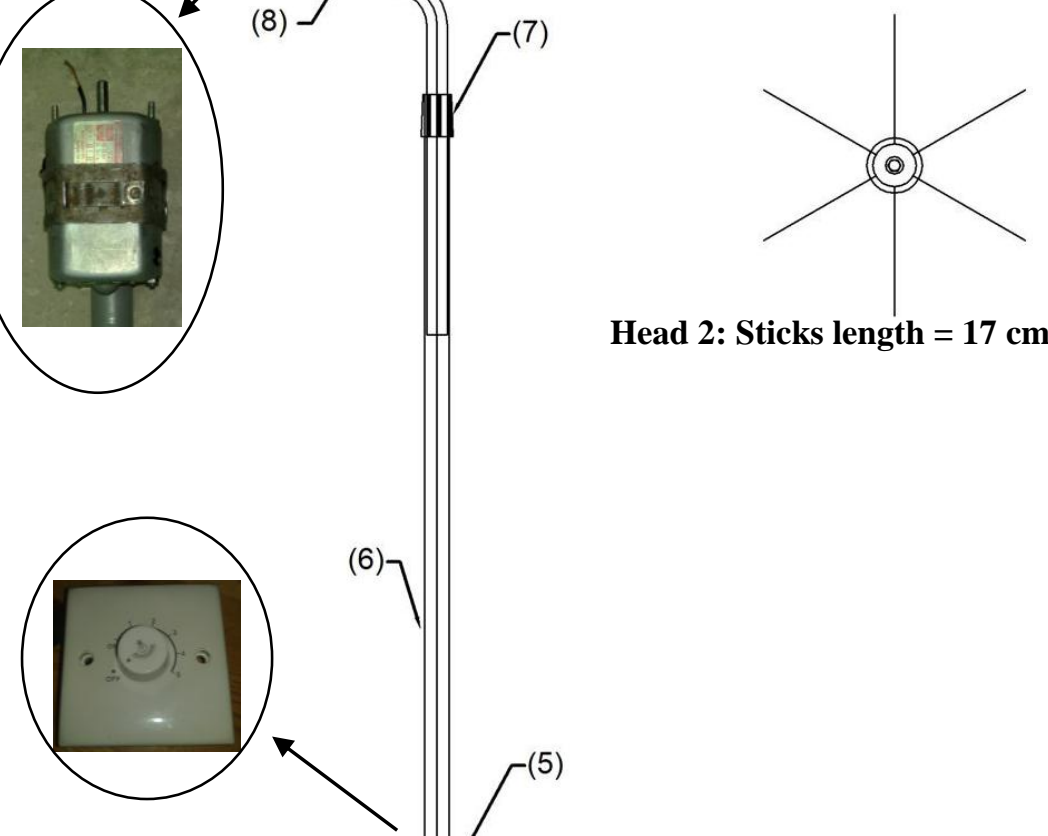

Head 2: Sticks length $=17 \mathrm{~cm}$
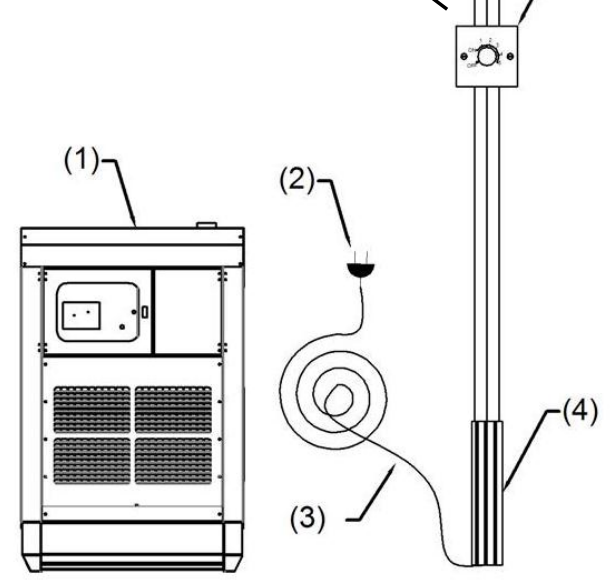

\begin{tabular}{|c|c|c|c|}
\hline 11 & 1 & \multicolumn{2}{|c|}{ Rotary Headcarrying 6 elastic thermoplastic sticks } \\
\hline 10 & 1 & Motor 60 Watt- $2000 \mathrm{rpm}$ & \\
\hline 9 & 1 & Base Motor & \\
\hline 8 & 1 & Extension rod $2,40 \mathrm{~m}$ length up to $3,4 \mathrm{~m}$ & withextension! \\
\hline 7 & 1 & Locking Nut & Plastic \\
\hline 6 & 1 & Main rod & Al \\
\hline 5 & 1 & Regulator Switch & \\
\hline 4 & 1 & handle & Plastic \\
\hline 3 & 1 & Electrical cable & \\
\hline 2 & 1 & Socket & \\
\hline 1 & 1 & Portable Generator $700 \mathrm{~W}$ & \\
\hline Itemref & Quantity & Title/Name & Material \\
\hline \multicolumn{2}{|c|}{\begin{tabular}{|l|} 
Designed by \\
Dr./Mohamed Ibrahim
\end{tabular}} & Checked by & \\
\hline
\end{tabular}

Fig. (2): The electrical hand-held harvester. 

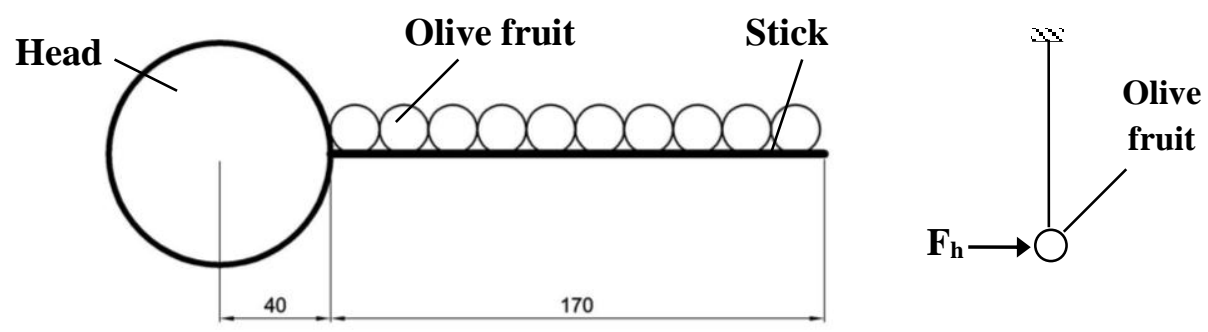

Dims. in mm

Fig. (3): Head $\left(\mathrm{H}_{2}\right)$ of olive harvester.

\subsubsection{The olive harvester}

The machine had one handle and it was gripped by one operator's hand and a telescoping rod up to a maximum length of $2.9 \mathrm{~m}$.

The harvesting mechanism contains 6 elastic sticks that allow for easy and deep access to all types of foliage without getting caught in the branches. The elastic sticks fixed with the head.

There are two harvesting heads (Fig. 2) were used. The first head $\left(\mathrm{H}_{1}\right)$ has diameter of $10 \mathrm{~mm}$ and length of $6 \mathrm{~cm}$. The second head $\left(\mathrm{H}_{2}\right)$ has diameter of $10 \mathrm{~mm}$ and length of $17 \mathrm{~cm}$.

\subsubsection{The required power of the developed machine}

- Let take head $\left(\mathrm{H}_{2}\right)$ that has stick length of $17 \mathrm{~cm}$ as shown in Fig. (3).

- The number of fruit that stick can moves olive at simultaneously fruits = stick length/ fruit diameter $=10$ fruits.

- The required force $\left(F_{h}\right)$ to oscillate the one fruit $=0.05 \mathrm{~N}$ (it was measured by using dynamometer).

- It can calculate the torque for one stick of the head by the following equation:

$$
T=\sum_{i=1}^{10} F_{h} \cdot r_{i}=\mathrm{F}_{\mathrm{h}} \cdot \mathrm{r}_{\mathrm{av}} \cdot \mathrm{N}_{\mathrm{f}}
$$

Where

T : Torque for one stick of the head, N-m.

$F_{h} \quad$ : Required force to oscillate the one fruit, $\mathrm{N}=0.05 \mathrm{~N}$. 
$\mathrm{r}_{\mathrm{i}} \quad: \quad$ The distance from the center gravity of fruit and the center of head at fruit number (i).

i : Number of fruit $i=1,2,3, \ldots . .10$.

$\mathrm{r}_{\mathrm{av}}$ : The average distance from the center gravity of fruit and the center of head at fruit, $\mathrm{m}=12.5 \mathrm{~cm}$.

$\mathrm{N}_{\mathrm{f}}$ : Number of fruits move by one stick $=10$ fruit.

Total torque of the head $=0.05 \mathrm{~N} \times 0.125 \mathrm{~m} \times 10$ fruit $\times 6$ sticks $=\mathbf{0 . 3 7 5}$

$\mathbf{N}-\mathbf{m}$.

The required power $(\mathrm{P})$ was calculated by the following equation:

$$
P=\frac{M_{t} \times 2 \pi N}{60}
$$

Where

$\mathrm{P} \quad$ : The required power, $\mathrm{W}$.

$\mathrm{M}_{\mathrm{t}} \quad$ : Torsional moment, $\mathrm{N}-\mathrm{m}=0.375 \mathrm{~N}-\mathrm{m}$.

$\mathrm{N}$ : Speed of head, $\mathrm{rpm}=1500 \mathrm{rpm}$.

From the previous equation the required power $(\mathrm{P})$ was calculated as $\mathbf{5 8 . 9}$ watt.

\subsubsection{Power unit and electrical source}

A small- sized electric motor (AC, $220 \mathrm{~V}-60$ watt - $2000 \mathrm{rpm}$ ) is used to operate the head mechanism

The electric motor is driven by a gasoline generator $(220 \mathrm{~V}-700$ watt $)$ through electrical wires passing inside pipes of telescopic rod. The operation regulated switch was fixed on the lower pipe of the frame rod in a suit place for operator. The function of the regulated switch is controlling the speed of harvester head.

\subsection{Evaluation criteria}

The performance of developed machine was measured by machine productivity, fruit removal percentage, fruit damage percentage, consumed energy and harvesting cost.The evaluation was done under the following variables as shown table (1).

Table (1): Experimental variables for evaluating the machine.

\begin{tabular}{ll}
\hline Variables & Levels \\
\hline Harvesting head type. & $\left(\mathrm{H}_{1}\right),\left(\mathrm{H}_{2}\right)$ \\
Head speed, rpm. & $700,1100,1500$ \\
\hline
\end{tabular}




\subsubsection{Machine productivity}

The total mass of detachment fruits using machine was recorded. The total harvesting time includes selecting, detaching fruit and the time required for moving machine between olive trees inside the field. The productivity of operated machine was calculated as follows:

$$
\mathrm{P}_{\mathrm{m}}=\frac{\mathrm{W}}{\mathrm{T}}
$$

Where

$\mathrm{P}_{\mathrm{m}} \quad$ : Productivity, $\mathrm{kg} \mathrm{h}^{-1}$.

W : Mass of harvested fruit, $\mathrm{kg}$.

$\mathrm{T}$ : Total harvesting time, $\mathrm{h}$.

\subsubsection{Fruit removal percentage (FR)}

It was calculated by the following equation (Polat et al. 2007):

$$
F R=\frac{K_{1}}{K_{1}+K_{2}} \times 100
$$

Where

$\mathrm{F}_{\mathrm{R}} \quad$ : Fruit removal percentage, $\%$.

$\mathrm{K}_{1} \quad$ : The mass of detachment olive fruit by the machine, $\mathrm{kg}_{\mathrm{g}} \mathrm{tre}^{-1}$.

$\mathrm{K}_{2} \quad$ : The mass of olive fruit which staying on the branch, $\mathrm{kg} \mathrm{tree}^{-1}$.

\subsubsection{Fruit damage percentage (FD)}

Fruit damage includes visual inspection and the fruit appears broken to the naked eye (Srivastava et al., 2006). Fruit damage was calculated by the following equation:

$$
F D=\frac{m d}{m t} \times 100
$$

Where

FD : $\quad$ Fruit damage percentage, $\%$.

$\mathrm{m}_{\mathrm{d}} \quad$ : Total mass of fruit damage, $\mathrm{kg}$.

$\mathrm{m}_{\mathrm{t}} \quad$ : Total mass of fruit harvested by the machine, $\mathrm{kg}$.

\subsubsection{Consumed energy (CE)}

The required electric power under working load (RP) was calculated as Chancellor (1981) by the following equation:

$$
\mathrm{RP}=\mathrm{V} \times \mathrm{I} \times \cos \theta
$$


Where

RP : The required power for operating the machine, watt.

$\mathrm{V} \quad$ : Potential difference, Voltage (I phase $=12$ voltage).

I : Current intensity, Amperes.

$\cos \theta \quad: \quad$ Power factor (0.64).

A digital clamp meter and voltmeter were used for measuring current intensity and voltage respectively.

The consumed energy (CE) is specific power per unit capacity; it was calculated by using the following equation:

Consumed energy $\left(\mathrm{W} . \mathrm{h} \mathrm{kg}^{-1}\right)=\mathrm{RP} / \mathrm{P}_{\mathrm{m}}$,

\subsubsection{Harvesting cost (HC)}

The harvesting costs of olive is expressed in terms of cost per hour and cost per unit of olive ( $1 \mathrm{~kg}$ ). Machine cost was determined using the fixed costs and variable costs according to Srivastava et al. (2006). The hand harvesting cost (L.E $\mathrm{Kg}^{-1}$ ) was recorded based on the labor daily salary and its productivity. The harvesting cost was determined using the following equation:

Harvesting cost $\left(\mathrm{L} . \mathrm{E} \mathrm{kg}{ }^{-1}\right) \quad=\frac{\text { Total cost }\left(\mathrm{L} . \mathrm{E} \mathrm{day} \mathrm{day}^{-1}\right)}{\text { Labor productivity }\left(\mathrm{kg} \mathrm{day}^{-1}\right)}$

\section{RESULTS AND DISCUSSIONS}

\subsection{Olive fruit properties}

Table (3) reports the some physical and mechanical properties of the harvested olives.

The mean value of detachment Force $\left(R_{F m}\right)$ for olive fruit with is $6.7 \mathrm{~N}$. So the minimum supporting load at olive stem-twig joints would be probably sufficient to detach the fruit by using rotational head of developed machine.

Table (3): Physical and mechanical properties of olive fruits.

\begin{tabular}{ll}
\hline Parameters & Values \\
\hline Fruit length $(\mathrm{L}), \mathrm{cm}$. & $\mathbf{2 . 1 3}$ \\
Fruit diameter $(\mathrm{d}), \mathrm{cm}$. & $\mathbf{1 . 7 2}$ \\
Volume $(\mathrm{v}), \mathrm{cm}^{3}$. & $\mathbf{3 . 1 6}$ \\
Fruit mass $(\mathrm{m}), \mathrm{g}$. & $\mathbf{3 . 1 0}$ \\
Fruit detachment force $\left(\mathrm{F}_{\mathrm{f}}\right), \mathrm{N}$. & $\mathbf{6 . 7}$ \\
Fruit detachment force to mass ratio $\left(\mathrm{R}_{\mathrm{Fm}}\right), \mathrm{N} / \mathrm{g}$. & $\mathbf{2 . 1 6}$ \\
\hline
\end{tabular}




\subsection{Performance characteristics of the harvesting machine}

Fig. (4) shows the calculated value of $\left(V^{2} / 10=F / m\right.$. $\left.r\right)$ that imparted on an olive fruit by using olive harvesting machine at different levels of head speed values and the length stick of the head. It may simply expect fruit detachment to occur as the inertial force due vibration exceeds the static tensile force required for fruit detachment $(6.7 \mathrm{~N}$ for ripe fruits, as listed in Table 3).

By applying rotational head machine, the minimum value of $\left(\mathrm{V}^{2} / 10\right)$ would be equal $(\mathrm{F} / \mathrm{m}$. r), to get probably sufficient for detachment fruit. With any olive variety, it can calculate the value of $(\mathrm{F} / \mathrm{m}$. r) and comparing this value with Fig. (4), it can be expected the removal efficiency of the developed machine and if it is suitable with this olive variety.

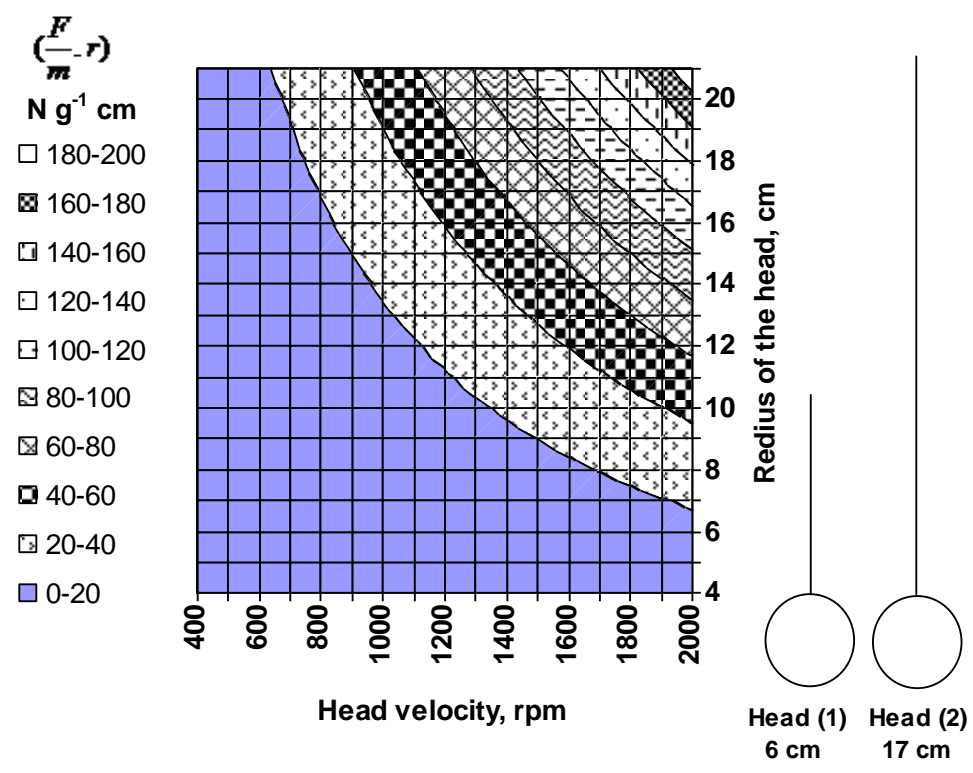

Fig. (4): Performance characteristics of the harvesting machine, that calculated value of $(F / m$. r).

\subsection{Machine productivity (Pm)}

Fig (5) shows the productivity of developed machine. The machine productivity ranged from 45.9 to $91.5 \mathrm{~kg} \mathrm{~h}^{-1}$ with head speed of 700 to $1500 \mathrm{rpm}$ and different head types $\left(\mathrm{H}_{1}, \mathrm{H}_{2}\right)$. The $(\mathrm{Pm})$ was the least at the lowest head speed of $700 \mathrm{rpm}$ and increased with increasing speed. This 
is due to increasing the impacted fruit by increasing the head speed. The (Pm) increased with change the head $\mathrm{H}_{1}$ by $\mathrm{H}_{2}$, this due to increase the stick length of head from $6 \mathrm{~cm}$ to $17 \mathrm{~cm}$, so increasing the number of impacted fruits in the harvesting fruit.

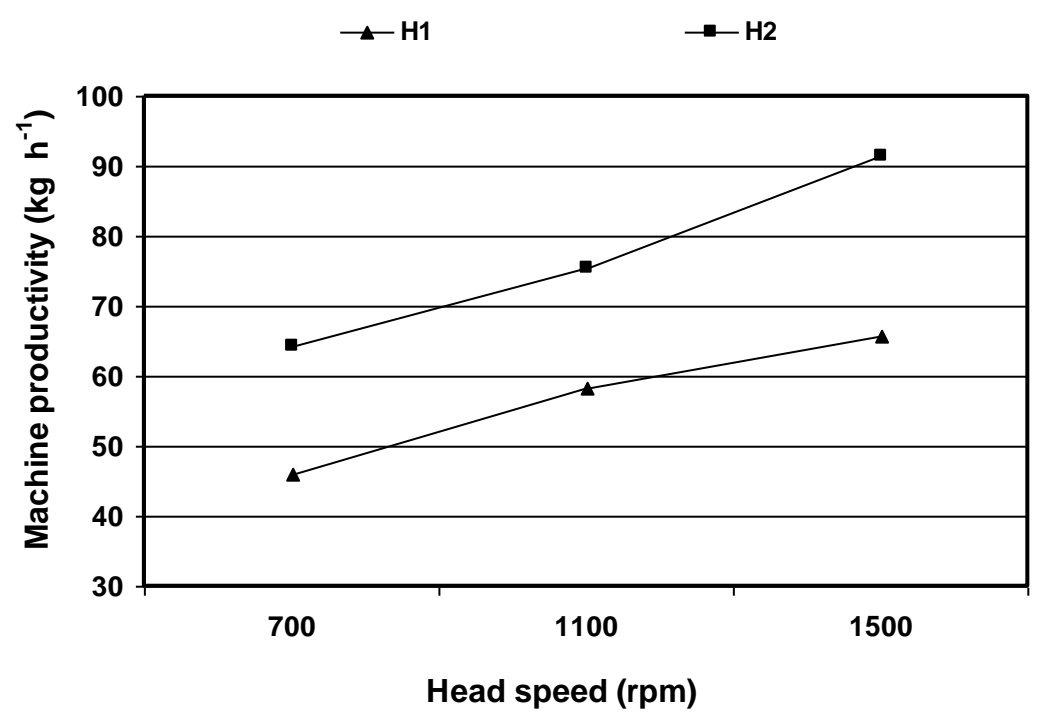

Fig. (5): Effect of speed and type of head on machine productivity.

\subsection{Fruit removal percentage (FR)}

Fig (6) shows the fruit removal percentage (FR) of developed machine. The (FR) ranged from 80.41 to $97.7 \%$ with head speed of 700 to 1500 rpm and different head types $\left(\mathrm{H}_{1}, \mathrm{H}_{2}\right)$. The (FR) was the least at the lowest head speed of $700 \mathrm{rpm}$ and increased with increasing speed. This is due to increasing the impacted fruit by increasing the head speed. The (FR) increased with change the head $\mathrm{H}_{1}$ by $\mathrm{H}_{2}$, this due to increase the stick length of head from $6 \mathrm{~cm}$ to $17 \mathrm{~cm}$.

\subsection{Fruit damage percentage (FD)}

Fig (7) shows the fruit damage (FD) of developed machine. The (FD) ranged from 4.5 to $6.23 \%$ with head speed of 700 to $1500 \mathrm{rpm}$ and different head types $\left(\mathrm{H}_{1}, \mathrm{H}_{2}\right)$. The (FD) was the least at the lowest head speed of $700 \mathrm{rpm}$ and increased with increasing speed. This is due to increasing the impacted fruit by increasing the head speed. The (FD) 
increased with change the head $\mathrm{H}_{1}$ by $\mathrm{H}_{2}$, this due to increase the stick length of head from $6 \mathrm{~cm}$ to $17 \mathrm{~cm}$ so, increasing in the damage fruit.

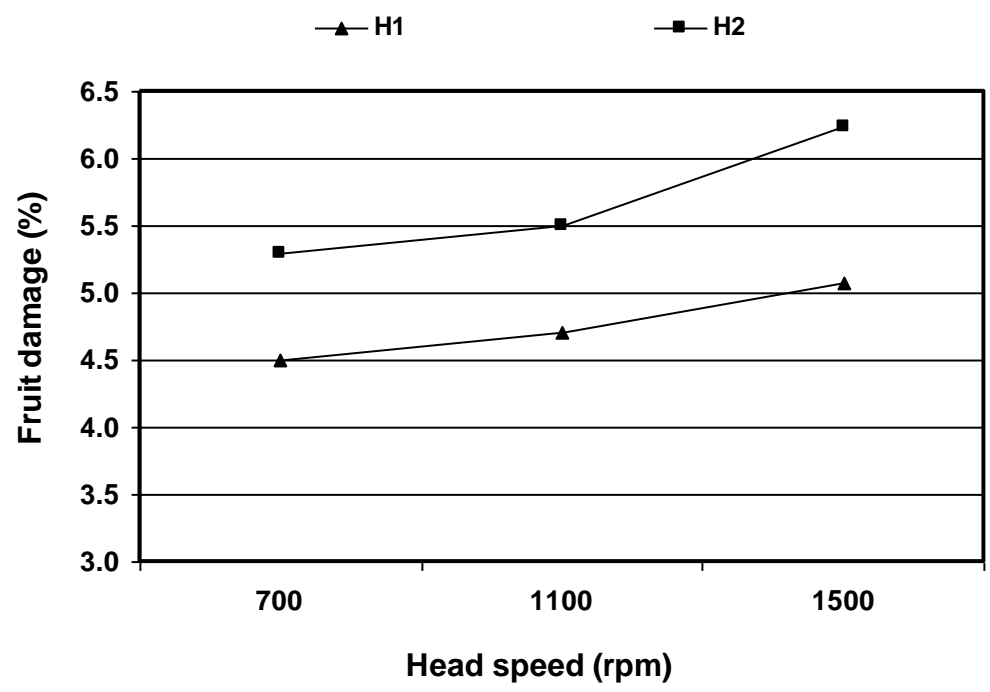

Fig. (6): Effect of speed and type of head on fruit removal percentage.

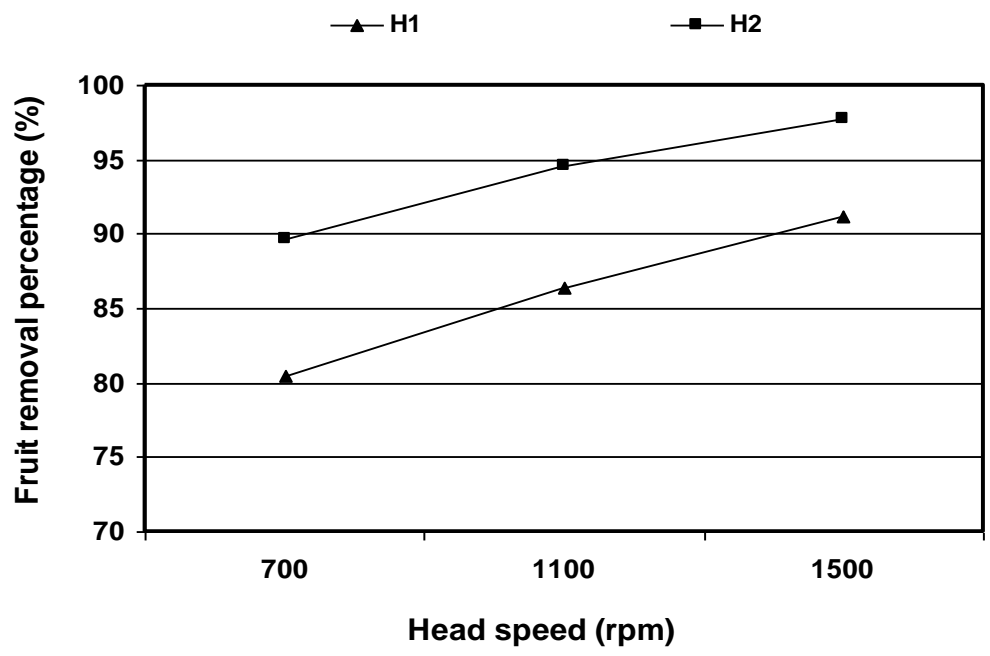

Fig. (7): Effect of speed and type of head on fruit damage.

\subsection{Consumed energy (CE)}

Fig (8) shows the consumed energy (CE) of developed machine. The (CE) ranged from 0.66 to $1.31 \mathrm{~W} \mathrm{~h} \mathrm{~kg}^{-1}$ with head speed of 700 to $1500 \mathrm{rpm}$ and different head types $\left(\mathrm{H}_{1}, \mathrm{H}_{2}\right)$. The (CE) was the heights at the lowest head speed 
of $700 \mathrm{rpm}$ and decreased with increasing speed. This is due to productivity increased by increasing the head speed the. The (CE) increased with change the head $\mathrm{H}_{1}$ by $\mathrm{H}_{2}$, this due to increase the stick length of head from $6 \mathrm{~cm}$ to $17 \mathrm{~cm}$ so, increasing in the harvested fruit. In this study, the productivity and fruit damage level are the two concerned factors to evaluate the selected head speed and head type. The $\mathrm{H}_{2}$ could remove more fruits but also produce higher fruit damage of $6.3 \%$. Compared to $\mathrm{H}_{1}$ with lower productivity can get similar low fruit damage removal. It demonstrates that using the head $\mathrm{H}_{2}$ at ranges from 1100 to $1500 \mathrm{rpm}$.

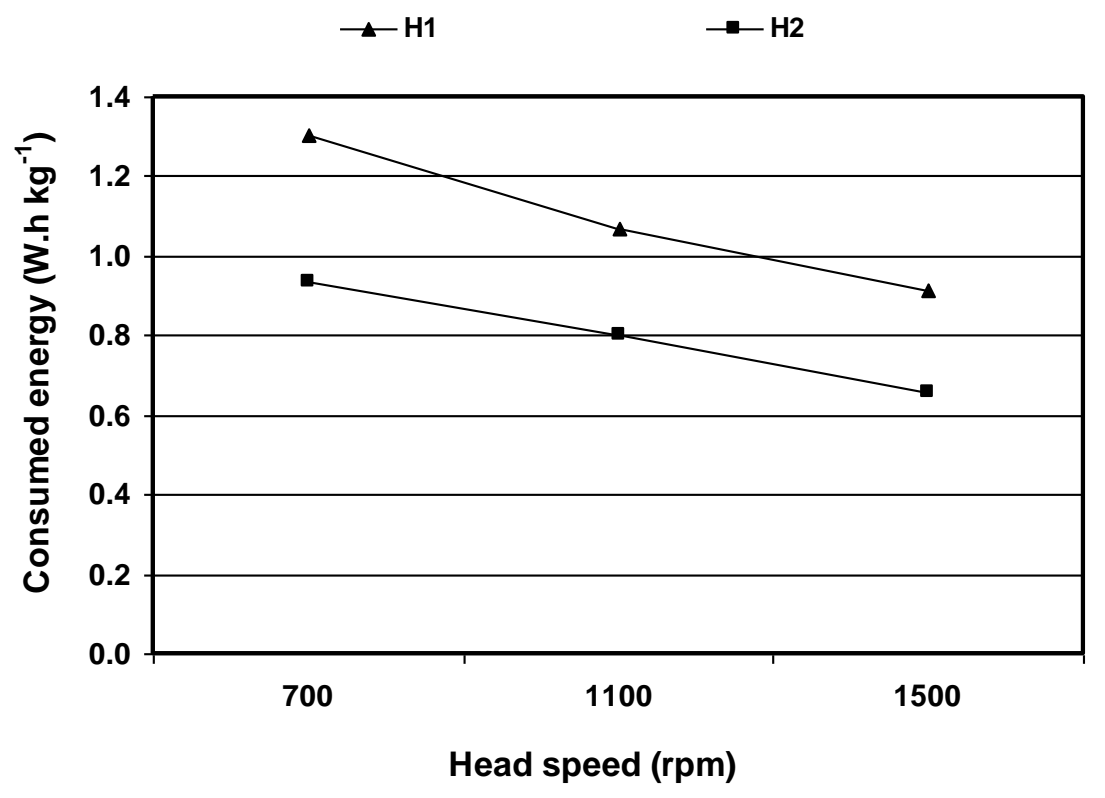

Fig. (8): Effect of speed and type of head on consumed energy.

\subsection{Techno-economic feasibility}

Fig. (9) shows the harvested olive fruits for one hour by the hand harvesting method and developed machine are 20 and $91.5 \mathrm{~kg}$, and the harvesting costs are 0.94 and $0.26 \mathrm{~L} . \mathrm{E} \mathrm{kg}$ k $^{-1}$ (according to 2018 local conditions) respectively. Using the developed machine increased harvesting productivity to about 4.58 times and reduced the harvest cost to about $72.34 \%$ comparing with hand harvesting method. These findings prove the feasibility of the developed machine with productivity and cost. 


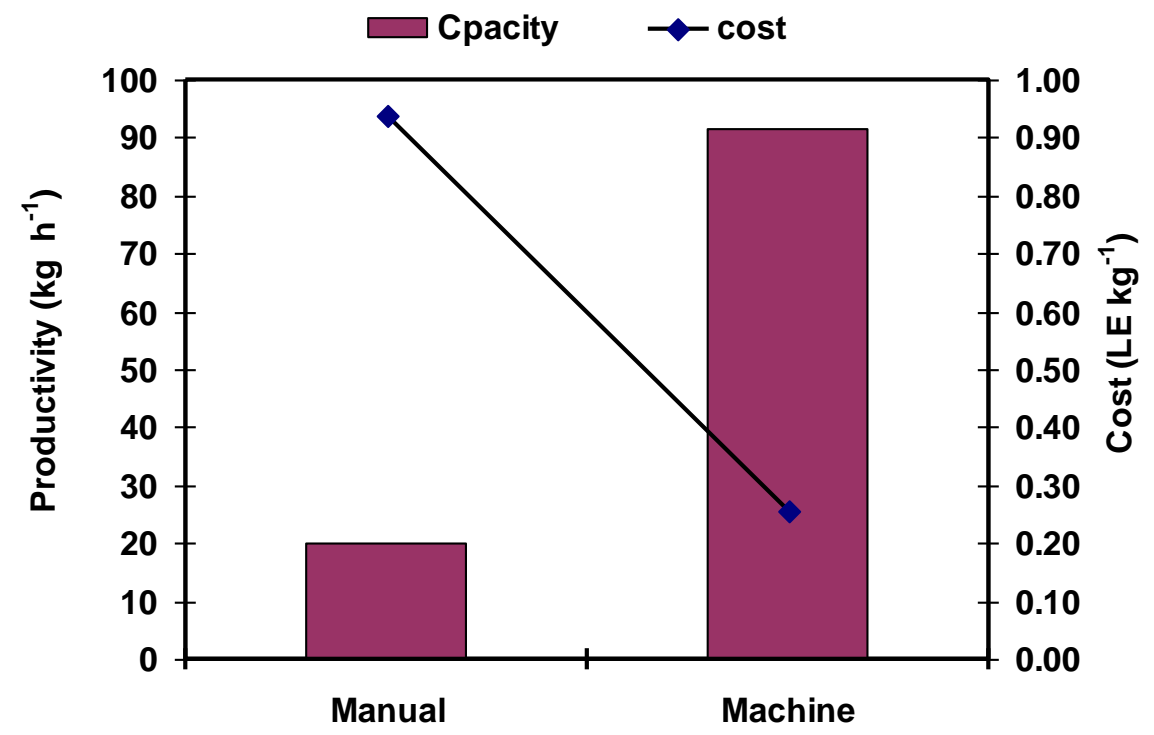

Fig. (9): Productivity and harvesting cost of the developed machine comparing with hand picking method.

\section{CONCLUSIONS}

The results of harvesting olive fruit by using developed hand- held machine can be summarized as follows:

1. Machine capacity increased with the increase of both head speed and stick length of the head.

2. Fruit removal percentage increased with the increase of both head speed and stick length of the head.

3. Fruit damage percentage increased with the increase both of head speed and stick length of the head.

4. Consumed energy decreased with the increase both of head speed and stick length of the head.

5. The most suitable machine perfect parameter conditions that realize the best harvesting condition were length $17 \mathrm{~cm}$ and head speed ranges from 1100 to $1500 \mathrm{rpm}$.

\section{REFRENCES}

Amirante, P., A. Tamborino. 2012. Olive Harvesting systems in high density orchards. Acta Horticulturae (ISHS) nº 949, 351-358. 
Castillo-Llanque F., H. F. Rapoport. 2009. Identifying the location of olive fruit abscission, Sci Hortic 120: 292-295.

Chancellor, W. J. 1981. Substituting information for energy in agricultural. Trans. ASAE Paper No. 0001- 2351.

Deboli, R. , A. Calvo, C. Preti and M. Inserillo. 2014a. Design and test of a device for acceleration reproducibility of hand held olive harvesters. International Journal of Industrial Ergonomics. 44: 581589.

Deboli, R., A. Calvo, F. Gambella, C. Preti, R. Dau and E. C. Casu. 2014b. Hand arm vibration generated by a rotary pick-up for table olives harvesting. Agricultural Engineering International; CIGR Journal. 16 (1): 228-235.

Famiani F., A. Baldicchi, D. Farinelli, L. Nasini, P. Proietti. 2010. L'efficienza dell'agevolatrice è influenzata dalla cultivar. Olivo e Olio 10.

Famiani F., A. Giurelli, P. Proietti, L. Nasini, D. Farinelli, P. Guelfi. 2008. Sì alla raccolta agevolata in oliveti tradizionali ed intensivi. L'Informatore Agrario. 4, 103-107.

Farinelli, D., S. Tombesi, F. Famiani and A. Tombesi. 2012. The fruit detachment force/fruit weight ratio can be used to predict the harvesting yield and the efficiency of trunk shakers on mechanically harvested olives. Acta Horticulturae, 965, 61-64.

FAOSTAT. 2018. FAO Statistical Yearbook. Agricultural production. http://www.fao.org/faostat. Accessed on August 2018.

Ferguson, L., U. A. Rosa, S. Castro-Garcia, S. M. Lee, J. X. Guinard, J. Burns, W. H. Krueger, N. V. O'Connell, K. Glozer. 2010. Mechanical harvesting of California table and oil olives. Adv. Hort. Sci. 24(1): 53-63.

Hegazi, E. S. 2009. Modern Techniques in the cultivation and production of olive. Modern Egyptian Office, 496 P.

IOOC. 2015. International olive oil production cost study. International Olive Council. October 2015. 
Mansour, H. A., T. A. Elmesiry, A. A. Abdelhady. 2018. Cost analysis of olive harvesting by hand-held machine. World Wide Journal of Multidisciplinary Research and Development. 4(2): 361-363.

O'brien, M., B. F. Cargill and R. B. Fridley. 1986. Principles and Practices for harvesting fruits and nuts. AVI publishing comp., INC., Westport, Connecticut.USA, 636pp.

Ozarslan, C., T. Saracoglu and T. Akbas. 2001. Development of hand type pneumatic olive beater. In 20 National Congress on Mechanization, Sanliurfa, Turkey: 239-244.

Paschino, F., M. Caria, and F. Gambella. 2010. The harvest of table olives from the plant by means of an hand harvester. In Proc. International Conference on "Work Safety and Risk Prevention in Agro-food and Forest Systems", Ragusa, September 16-18: 656660.

Polat, R., I. Gezer, D. Erdogan, M. Guner, E. Dursun, H. I. C. Bilim. 2007. Mechanical harvesting of pistachio nuts. Journal Food Engineering. 79: 1131-1135.

Srivastava, A. K., C. E. Goering, R. P. Rohrbach and D. R. Buckmaster. 2006. Engineering principles of agricultural machines. St. Joseph, Mich.: ASAE.

Tombesi, A., M. Boco, M. Pilli, D. Farinelli. 2002. Influence of canopy density on efficiency of trunk shaker olive mechanical harvesting. Acta Horticulturae. 586: 291-294.

Tsatsarelis, C. A., C. B. Akritidis and A. J. Siatras. 1984. Classification of olive varieties for effective mechanical harvesting.Transactions of the ASAE. 27(6): 1669- 1673.

Vieri, M., D. Sarri. 2010. Criteria for introducing mechanical harvesting of oil olives: results of a five-year project in Central Italy. Adv. Hort. Sci. 24 (1): 78-90.

Visco, T., M. Molfese, M. Cipolletti, R. Corradetti and A. Tombesi. 2004. Influence of training system, variety, and fruit ripening on efficiency of mechanical harvesting of young olive trees in Abruzzo, 
Italy. Fifth International Symposiumon Olive Growing, and Izmir, Turkey, Abstract CM28.

Zhou, J., H. Long, K. Manoj and Q. Zhang. 2016. Analysis of shakinginduced cherry fruit motion and damage. Biosystems Engineering, $144,105-114$.

الملخص العزبي

\section{تطوير آلة كهربائية محمولة لحصاد الزيتون

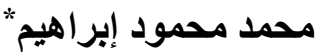

الزيتون أحد المحاصيل الهامة التي تزرع في منطقة حوض البحر البرد المتوسط. تكمن الأهمية

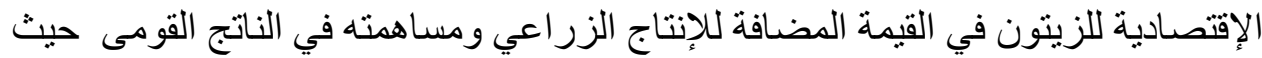

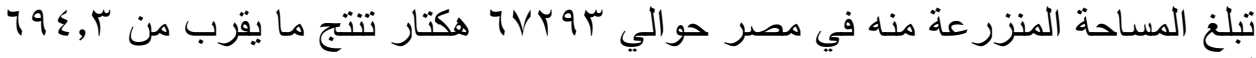

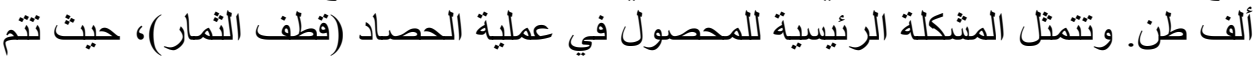

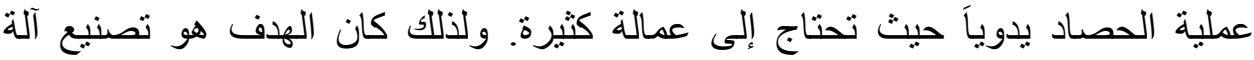
صغيرة محمولة تتاسب الحياز ات الصغيرة.

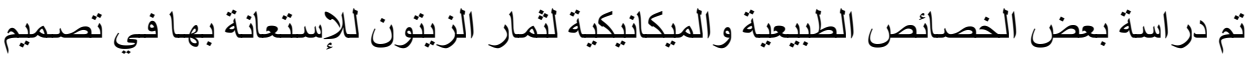

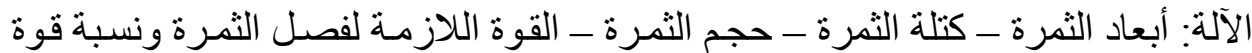

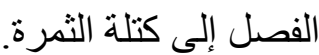
تم در اسة القوى المؤثرة على ثمرة الزيتون اثنـاء الحصـاد ــثم تم تصميم الآلتة و حسـاب

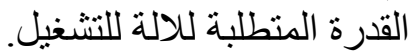

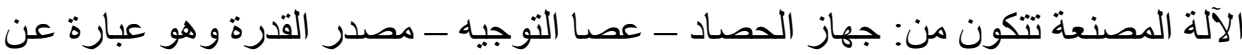

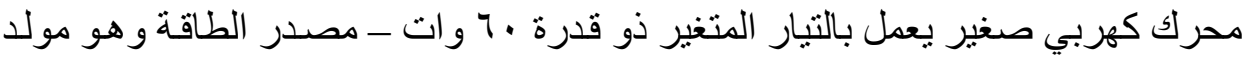

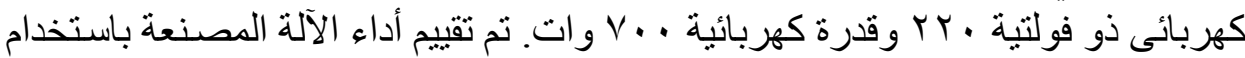

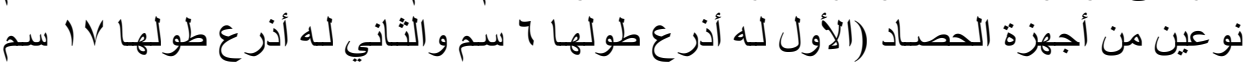

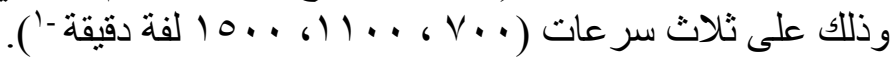

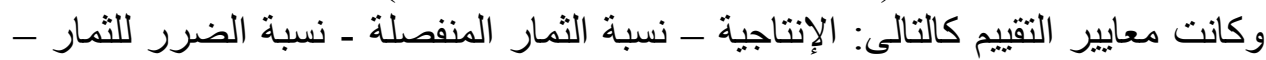

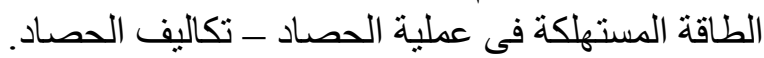

$$
\text { وقا بينت الاراسة ما يلي: }
$$

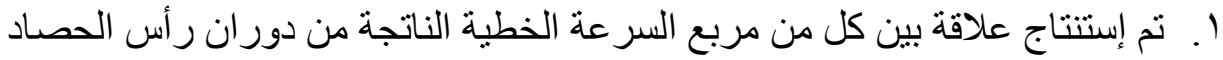

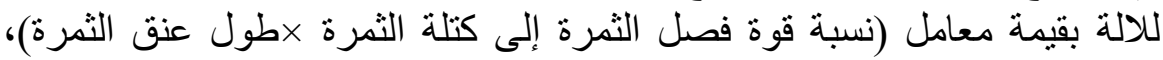

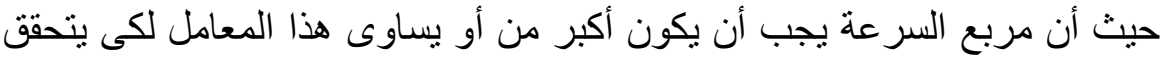

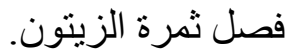


r. تم إستتناج خريطة كنتورية لأداء الآلة يمكن التنبؤ بقيمة معامل (نسبة قوة فصل

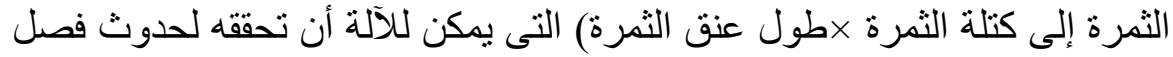

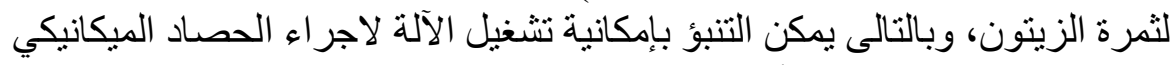

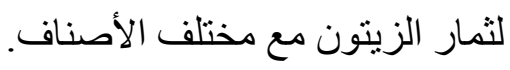

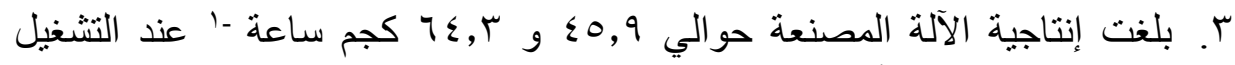

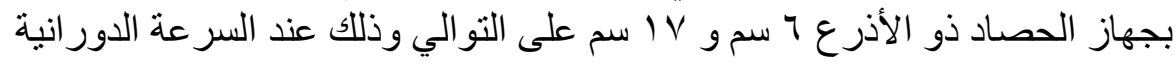

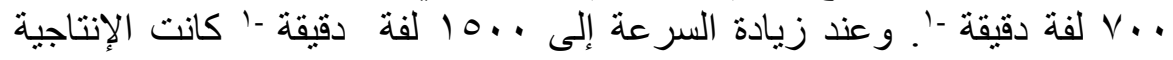

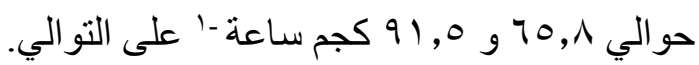

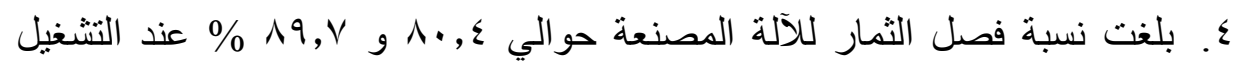

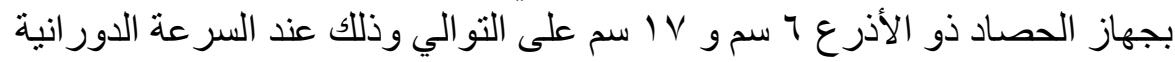

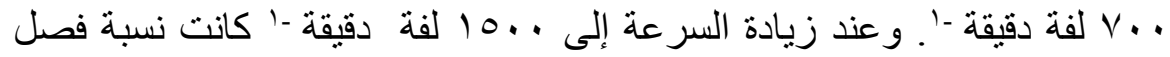

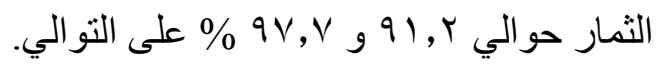

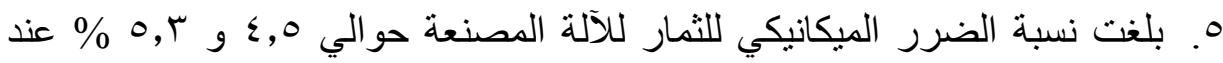

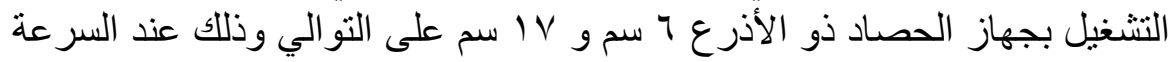

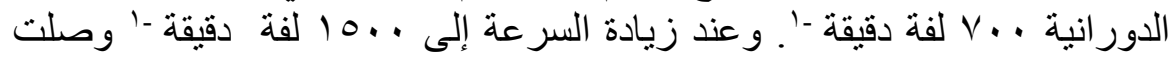

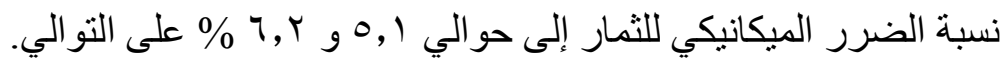

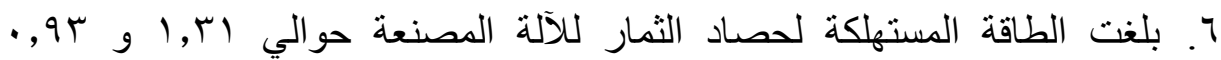

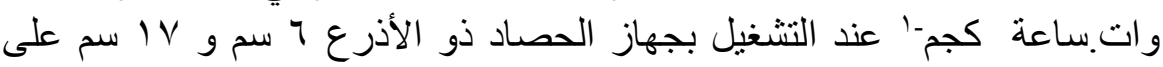

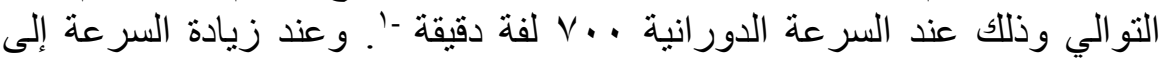

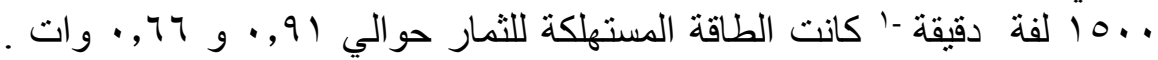

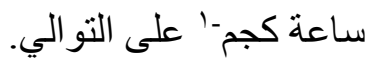

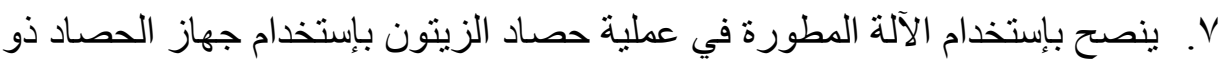

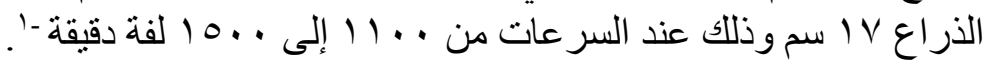

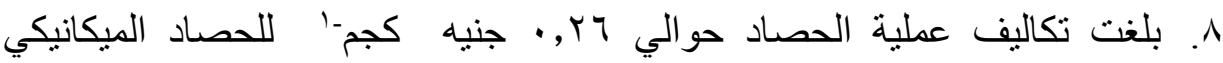

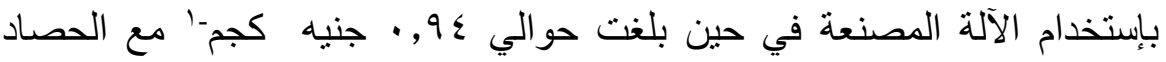

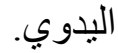

